\title{
INFLUENCE OF NON CARIOUS CERVICAL LESIONS DEPTH, LOADING POINT APPLICATION AND RESTORATION ON STRESS DISTRIBUTION PATTERN IN LOWER PREMOLARS: A 2D FINITE ELEMENT ANALYSIS
}

\author{
INFLUENNCIA DA PROFUNDIDADE DA LESÃO CERVICAL NÃO CARIOSA, \\ PONTO DE APLICAÇÃO DE CARGA E RESTAURAÇÃO NO PADRÃO DE \\ DISTRIBUIÇÃO DE TENSÕES EM PRÉ-MOLARES INFERIORES: 2D-ANÁLISE \\ POR ELEMENTOS FINITOS
}

\section{Livia Fávaro ZEOLA ${ }^{1}$; Fabrícia Araújo PEREIRA ${ }^{\mathbf{1}}$; Alexia da Mata GALVÃO ${ }^{\mathbf{2}}$; Tatiana Carvalho MONTES ${ }^{2}$; Sônia Cristina de SOUSA ${ }^{2}$;}

Daniela Navarro Ribeiro TEIXEIRA ${ }^{2}$; Bruno Rodrigues REIS ${ }^{3}$; Paulo Vinícius SOARES

1. Postgraduate Student and Member of Nucleus Extension, Research and Teaching at NCCL, Dentistry School, Federal University of Uberlandia, Brazil; 2. Undergraduate Student and Member of Nucleus Extension, Research and Teaching at NCCL, Dentistry School, Federal University of Uberlandia, Brazil; 3. Professor at Technical School of Health, and Member of Nucleus Extension, Research and Teaching at NCCL, Dental School, Federal University of Uberlandia, Brazil; 4. Associate Professor at Operative Dentistry and Dental Materials Department and Coordinator of Nucleus Extension, Research and Teaching at NCCL, Dentistry School, Federal University of Uberlandia, Brazil.paulovsoares@yahoo.com.br

\begin{abstract}
The aim of this study was to analyze the biomechanical behavior of lower premolars regarding the non-carious cervical lesion (NCCL) depth, load type and restoration status, using finite element analysis. Twodimensional virtual model simulating a healthy lower premolar were created using the CAD software. Based on this image, five models were generated: healthy $(\mathrm{H})$, three types of NCCLs: small lesion (SL -0.5 mm deep), medium lesion (ML - $1.0 \mathrm{~mm}$ ), deep lesion ( $\mathrm{DL}-1.5 \mathrm{~mm}$ ), and restored lesion (RL). The models were export to a CAE software (ANSYS Finite Element Analysis Software), the areas of all structures were plotted and each model was meshed using a control mesh device. All of the virtual models were subjected to two occlusal load types, (100N each): occlusal load (OL) and buccal load (BL) on buccal cusp. The magnitude and the stress distribution were obtained using the von Mises and maximum principal stress criteria $(\sigma 1)$, in $\mathrm{MPa}$. The quantitative analysis of stress $(\mathrm{MPa})$ was identified at three points of the NCCLs: enamel surface on its upper wall, dentin at the bottom wall and dentin on the lower wall. The results showed a direct relation between sequential removal of cervical structure and higher stress concentration for any groups and for both loads types. For OL the highest value of stress was $8.8 \mathrm{MPa}$ for DL on upper wall of NCCLs. The BL exhibited higher stress values in comparison to the OL for all models.In addtion, the BL was responsible for providing the highest stress accumulation on the bottom wall, $38.2 \mathrm{MPa}$ for DL. The restoration with composite resin was able to restore a stress distribution close to the healthy model, for both load types. In conclusion, the extent of non-carious cervical lesion and loading conditions influenced the stress distribution pattern of lower premolar. The outer load seems to be more critical in affecting the biomechanical behavior of lower premolars, regardless of the lesion size. The restoration of NCCLs with composite resin appears to recover the biomechanical behavior, similar to healthy model.
\end{abstract}

KEYWORDS: Finite element analysis. Non carious cervical lesion. Premolar.

\section{INTRODUCTION}

Non-carious cervical lesions (NCCLs) are a routinely and increasingly found in dentistry clinical practice 1. This kind of lesion is a pathological process described by hard tissue dental loss at the cement-enamel junction (CEJ) independent of bacterial process (BORCIC et al,. 2004; REYES et al., 2009). It is generally accepted that the formation and progression of NCCLs are a multifactorial process, involving the stress (abfraction), biocorrosion (chemical, biochemical and electrochemical degradation) and friction (wear) (GRIPPO et al., 2012). The areas most affected by cervical lesions are the buccal faces, with highest prevalence in the upper and lower premolars (SMITH et al., 2008).

The prevalence of NCCLs occur in up to 85 percent of individuals, increasing with age (SMITH et al., 2008). This fact suggests a fatigue component in NCCLs formation associated with occlusal interferences (BRANDINI et al., 2012; WOOD et al., 2009) or any event that changes the dental occlusion, such as parafunction (BRANDINI et al., 2012), bruxism (OMMERBORN et al., 2007) and restorative procedures (BERNHARDT et al., 2006). These events alter the stress distribution pattern in the cervical region and can lead to weakening of the 
continuity between the hard tooth structures, resulting in possible microcrack initiation and rupture of rigid structures such as enamel (LEE W. C.; EAKLE 1984; REES, 2002; REYES et al., 2009). Studies reported that occlusal load position modifies the intensity of stress concentration in cervical regions (BENAZZI et al., 2014; REES, 2002; REES et al., 2003). The loads applied obliquely to the long axis of the tooth may promote an increase of stress in the cervical region and are related to the formation and progression of NCCLs (SOARES et al., 2014; REES, 2002; SOARES et al., 2013).

The selection of appropriate direct material to restore the NCCLs is an important step in the treatment process. At this stage, should be evaluated aesthetics, the presence of dentinal sensitivity (MICHAEL et al., 2009), as well as the amount of lost tooth structure. The literature reports different restorative materials to restore NCCLs, such as flowable composites, glass ionomer cement, resinmodified glass ionomer, and composite resins (MICHAEL et al., 2009; ONAL; PAMIR, 2005; STEWARDSON et al., 2012).

Finite element analysis (FEA) has been shown as a powerful tool in dental biomechanics for measuring stress distribution pattern in teeth and restorations in response to different occlusal loads(BORCIC et al., 2005; POIATE et al., 2009; VASUDEVA and BOGRA, 2008). This method enables the simulation of commonly observed clinical situations and the evaluation of different factors in various dental tissues, based on their biological mechanical properties (DEJAK and MLOTKOWSKI, 2011; REES et al., 2003; SILVA et al., 2009).
The treatment of non carious cervical lesions is still a subject that generates discussion among clinicians. Despite the amount of studies related to non-carious cervical lesions, some issues still need to be investigated. The literature reports that lesions in early stage should not be restored (ZUCCHELLI, et al.,2011). On the other hand, there are reports that oblique loads associated with deep lesions, provide large accumulation of tension in the cervical region, tending to its evolution. For this reason, the relationship between NCCLs sizes and occusal loads for premolars teeth remains unknown. In this context, the aim of this study was to analyze the stress distribution pattern of mandibular premolar teeth according to NCCLs deep, restorative status and occlusal loading direction, using finite element analysis.

\section{MATERIALS AND METHODS}

Two dimensional finite elements models were created based on a scan image of a healthy lower premolar. The scan data were exported to a computer-aided design software (Autodesk Mechanical Desktop 6; Autodesk Inc., San Rafael, California) to generate the external contours of enamel, dentine, pulp, polyether and polystyrene cylinder. These contours were made by point and line association using a polyline module of CAD software. Five 2D FEA models were created representing the study groups: healthy tooth-H, three types of NCCLs size: small lesion-SL $(0.5 \mathrm{~mm}$ depth), medium lesion-ML (1.0mm), deep lesionDL $(1.5 \mathrm{~mm})$ and deep restored lesion with composite resin-RL (Figure 1).
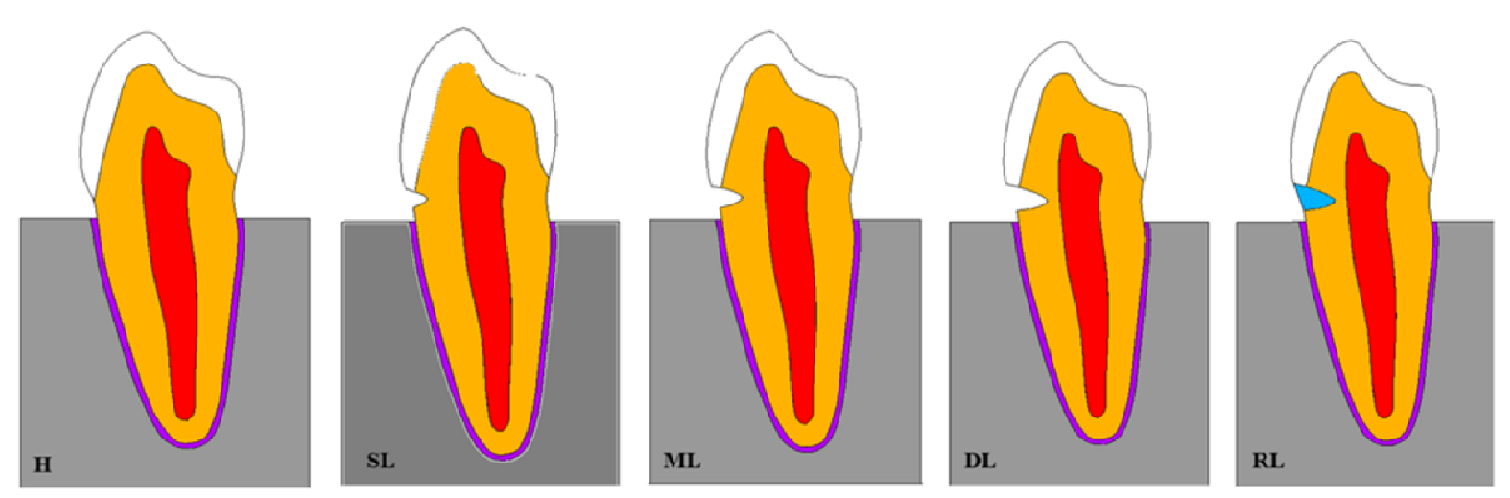

Figure 1. Description of five study groups. H) Healthy tooth; SL) Small lesion (0.5 mm deep); ML) Medium lesion (1.0 mm deep); DL) Deep lesion (1.5 mm deep); and RL) Restored lesion.

The data obtained were exported to CAE (Computer-aided engineering) software (ANSYS 12.0, ANSYS Inc., Houston, USA), using the
*.IGES format (Figure 2A), before they were processed in three steps. The pre-processing step was comprised of areas definition, insertion of tooth 
structure mechanical properties into the model, mesh and designation of boundary conditions. The processing step essentially involved calculation of stress values at different parts of NCCLs. The postprocessing step involved stress distribution analysis inside and around the NCCLs.
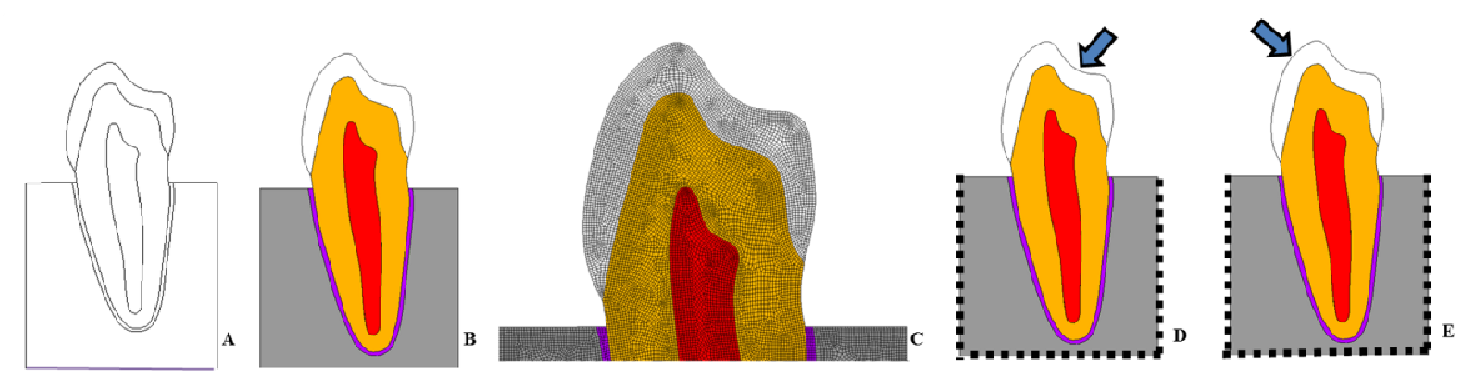

Figure 2. Two-dimensional finite element models generation. A) External and internal contours in CAD software; B) Areas visualization of dental tissues and structures in ANSYS software; C) Mesh representation of structures; D) Occlusal Load; E) Buccal Load.

Areas corresponding to each structure were plotted (Figure 2B) by linear associations and meshed with controlled and connected elements (Figure 2C). The meshing process involved the division of the system being studied into a set of small discrete elements defined by nodes. Eightnoded isoparametric plane elements (PLANE 183) were used, in accordance to the mechanical properties of each structure described in the literature (Table 1).

Table 1. Mechanical properties used to construct two-dimensional finite element models of teeth.

\begin{tabular}{ccc}
\hline Structures & \multicolumn{2}{c}{ Isotropic Structures } \\
\hline Pulp (TOPARLI, 2003) & 2 & Poisson Ratio (v) \\
\hline $\begin{array}{c}\text { Polyether (SOARES et al., 2008) } \\
\text { Polystyrene Resin (SOARES et al., } \\
\text { 2008) }\end{array}$ & 68.9 & 0.45 \\
& 13700 & 0.45 \\
Composite Resin (JOSHI,2011) & & 0.30 \\
\end{tabular}

The pulp tissue, polyether, polystyrene resin and composite resin were modelled in the FEA as elastic, isotropic and homogenous materials, whereas enamel and dentin were assumed to be orthotropic structures. A perfect bond was assumed when creating meshes between the composite restoration and the tooth structure in the deep lesion.

Two types of oblique loads $(100 \mathrm{~N})$ were applied to the buccal cusp of each model separately on the internal surface (occlusal load-OL) (Figure 2D) and outer surface (buccal load -BL) (Figure
2E). All nodes of the side and base of the polystyrene cylinder were restricted in all degrees of liberty (Figures 2D and 2E). The intensity of maximum principal stress $(\sigma 1)$ and von Mises analysis were evaluate for all the models. Three points in each NCCL were chosen for quantitative analysis of stress (MPa), including the enamel surface on its upper wall (UW), dentin at the bottom wall (BW) and dentin on the lower wall (LW). 


\section{RESULTS}

The qualitative and quantitative analysis of FEA can be demonstrated in figures 3, 4 and 5 . The von Mises showed a direct relation between sequential removal of cervical dental structure and
ZEOLA, L. F. et al.

higher stress concentration for any groups and for both loads types (Figure 3). High levels of stress were found in vestibular face, force application areas and in dentine inside the lesion area for all models. The deepest lesion showed the greater stress concentration for $\mathrm{OL}$ and $\mathrm{BL}$ (Figure 3).
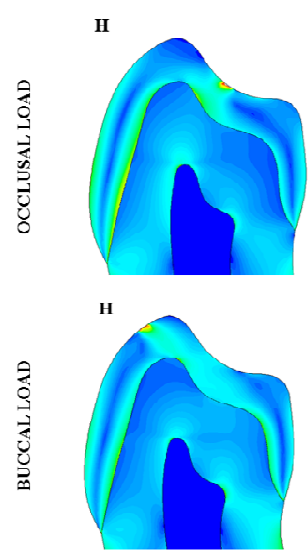

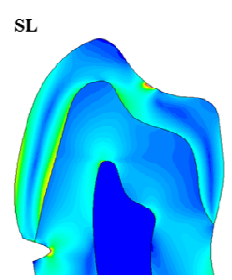

SL

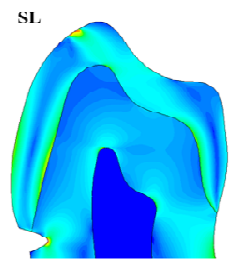

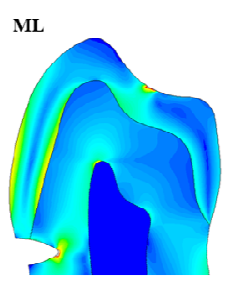

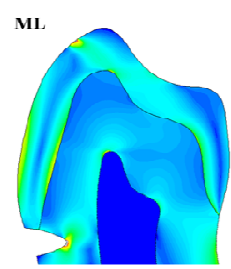

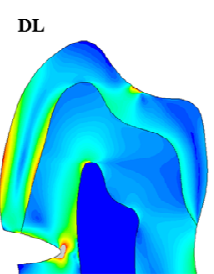

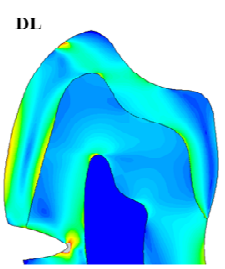

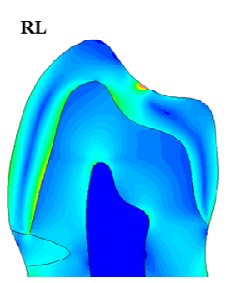

RL.

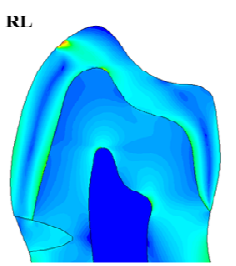

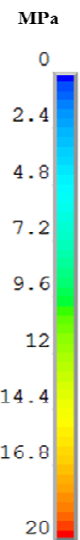

Figure 3. von Mises stress distibution (MPa) of all models under occlusal and buccal load. H) Healthy tooth; SL) Small lesion; ML) Medium leion; DL) Deep lesion; RL) Restored lesion.

In maximum principal stress analysis, the loading direction had a significant difference on the stresses distribution pattern. The occlusal load resulted in high tensile stress concentration on the superficial enamel of the buccal cusp and around the upper wall of the lesions (Figure 4)
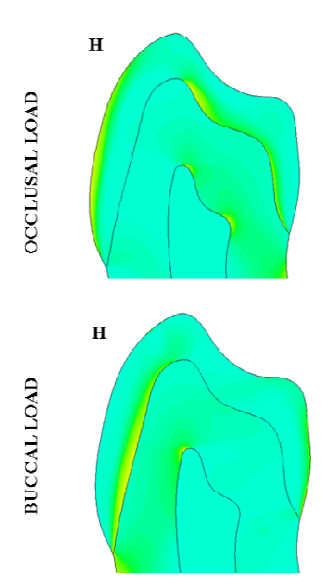
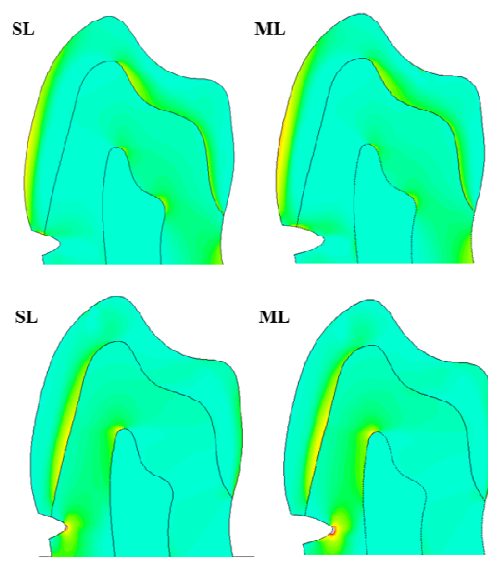

ML

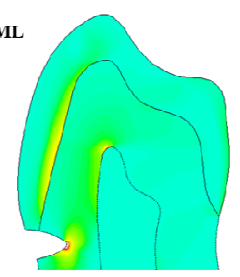

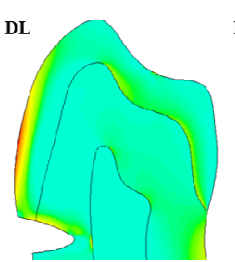

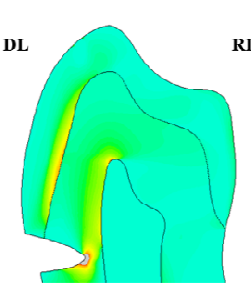

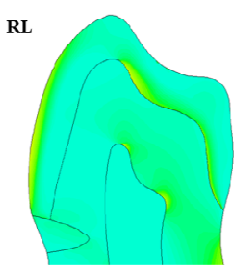

RL

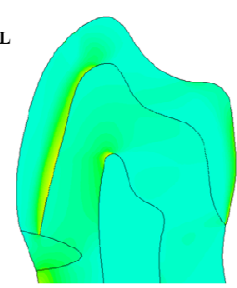

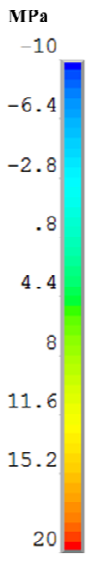

Figure 4. Maximum principal stress distribution (MPa) of all models under occlusal and buccal load. $\mathrm{H}$ ) Healthy tooth; SL) Small lesion; ML) Medium lesion; DL)Deep lesion; RL) Restored lesion.

Highest values of tensile stress were found at point UW for ML and DL, with values of 6.7 and $8.8 \mathrm{MPa}$, respectively (Figure 5). On the other hand, the buccal loads increased the stress concentration at the dentino-enamel junction and the buccal pulp horn, as well as at the bottom of NCCLs (Figure 4). The BL promoted greathest values at point $\mathrm{BW}$ of ML (29 MPa) and DL (38.2 MPa) (Figure 5). 


\section{$\mathrm{MPa}$}

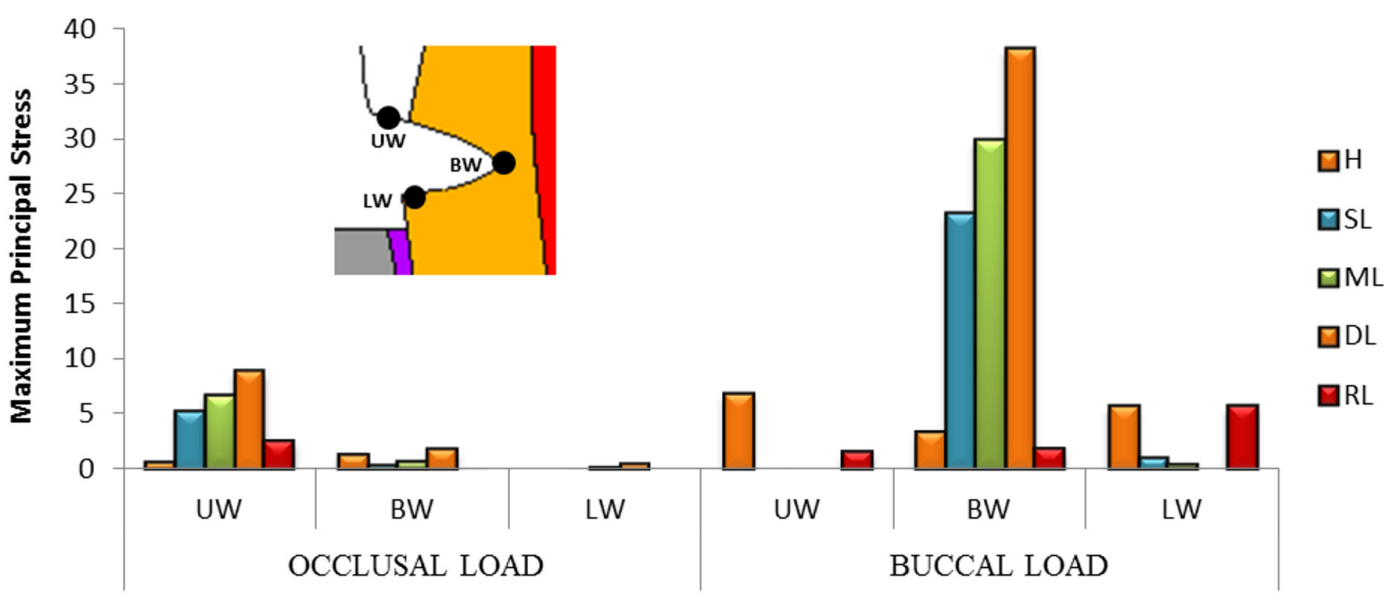

Figure 5. Maximum principal stress values obtained from finite element analysis on three specific points within NCCL subjected to the occlusal and buccal load (in MPa). UW) Upper wall of the lesion in enamel; $\mathrm{BW}$ ) Bottom wall of the lesion in dentine and LW) dentin on the lower wall.

Stress distribution for RL was similar to the behavior of the healthy tooth model, for both loading directions (Figures 3 and 4). The restored models presented low stress levels in the cervical regions, with highest stress values $2.5 \mathrm{MPa}$ and 5.6 $\mathrm{MPa}$ for OL and BL, respectively (Figure 5).

\section{DISCUSSION}

The findings of the present study showed that the NCCLs size and load point application plays an important role on stress distribution pattern in lower premolars.

Finite element analysis in the present study indicates that the presence of NCCLs promoted changes on stress distribution pattern due to the loss of dental structure (SOARES et al., 2008). NCCLs, even as small $(0.5 \mathrm{~mm}$, ) generated high stress concentration in the cervical region, with the stress magnitude increasing with lesion size (Figure 3 and 4). This fact suggests that the stress generated by the lesion presence may be a factor that leads to progression of the NCCLs (SOARES et al., 2013). For this reason, the treatment of shallow lesions should be taken into consideration in dental clinical practice, since only its monitoring, without the control of the etiological factors and without the restoration, can provide an acceleration of tooth structure loss process.

The biomechanical behavior of the teeth affected by NCCLs varies according to the loading direction (REES, 2002; VASUDEVA and BOGRA, 2008; SOARES et al., 2014; BENAZZI et al., 2014). High stress concentration is generated from occlusal loading during tooth chewing and others types of parafunctions (REES, 2002; WOOD et al., 2009). The results of this study demonstrated that each type of load generate stress concentration in different regions. This finding ratifies that different positions of occlusal contacts promote changes in tensile stress magnitude in the cervical region, that tend to be able to initiate failure (REES, 2002). This load application promotes compressive and tensile stress acting on the tooth structure, influencing on disruption of chemical bonds between the enamel crystals in cervical region (BORCIC et al., 2005; LEE H. E. et al., 2002), accelerating the tooth structure loss.

The presence of a traumatic dental occlusion is considered an important factor for the occurrence of NCCLs (BRANDINI et al., 2012). A better understanding of the influence of the applied loads may help a clinician select more biomechanically satisfactory restorative treatment to reduce the incidence and severity of NCCLs. Our findings showed that occlusal loading produced tensile stress in the upper wall of NCCLs, and the buccal loading generated tensile stress in the bottom region of NCCLs (Figure 4). Furthermore, the magnitude of tensile stress was greater for outer loading than inner loading (Figure 5). The stress acumulation in UW point for OL suggests a progression of the lesion towards the long axis of the tooth, which is increasing in height. On the other hand, the presence of stress at the bottom of the lesion (BW) generated by $\mathrm{BL}$, may tend to lead to increasing injury in the horizontal direction, thus characterizing an evolution in depth. 
In addition, the results of this study showed a high stress concentration in LW point associated with buccal load in RL model (Figure 5). This region represents an area close to the adhesive interface. The restorative procedure failure usually occurs in consequence of the stress accumulation on the restorative material and adhesive interface, mainly when submitted to oblique loading (ICHIM et al., 2007). This stress promotes great strain on the material, resulting in initial micro cracks, adhesive/cohesive failure and low material resistance (ICHIM et al., 2007). Therefore, the homogeneus distribution of occlusal contacts is a factor that deserves more attention for the opportune diagnosis and management of NCCLs (BORCIC et al., 2005).

The treatment of non-carious cervical lesions should seek not only restore the lost tissue (MICHAEL et al., 2009), but also the control of all etiological factors involved (GRIPPO et al., 2012; GRIPPO et al., 2013; SOARES et al., 2008). The decrease in stress concentration in NCCLs after replacement of a composite resin (Figures 3 and 4), provides some support for its use in restoring these lesions (SOARES et al., 2013).

The composite resin that restore NCCLs, regardless of the type of loading, has demonstrated better stress distribution, similar to the healthy model, due to the mechanical properties of composite resin (SENAWONGSE et al., 2010). The literature contains many examples materials for the NCCLs restoration, which have their advantages and disadvantages according to the clinical situation. Nonetheless, the restoration with composite resin was used as a restorative treatment of choice by authors (ICHIM et al., 2007) because of its aesthetics, longevity and ability of adhesion (BURROW and TYAS, 2008, CHEE et al., 2012) to tooth structure (SENAWONGSE et al., 2010). The adhesive restorative procedure must act to restore the structural integrity and biomechanical function of the injured teeth to a condition resembling that of healthy ones. In association, the composite resins present elastic modulus similar to dentine, which may be considered sufficient to offset the stress generated by occlusal forces (SENAWONGSE et al., 2010).
On the other hand, in this study a twodimensional analyses associated with the simplified representation of the tooth structures were used. For this reason, some characteristics of the restorative process were not simulated, as the polymerization shrinkage. This factor is inherent to the restorative material and should be considered in future studies, so that the behavior of the restorative material in the cervical region can be analyzed as well its influence on the all dental element.

In addition, despite this study provides a biomechanical viewpoint explanation for NCCLs, finite element analysis is limited in determining how NCCLs are formed and in simulating a situation with all etiologic factors involved.

Other studies should be made to better understand of the biomechanical behaviour of NCCLs. Tridimensional FEA analysis and experimental studies incorporating strain gauge analysis, fracture tests and clinical trials researches are necessary to elucidate and achieve the knowledge of biomechanical behaviour of NCCLs.

\section{CONCLUSIONS}

The stress concentration seemed to increase as the NCCLs depth increases. The presence of the deepest lesion associated with outer load promoted higher tensile stress concentration inside the lesion and on cervical region.

The loading type was modulator factor on stress distribution pattern of premolars. The buccal load showed the highest stress values and seems to be more damaging to tooth structure when compared to occlusal load.

The composite resin restoration presence influenced the stress distribution pattern of the affected teeth and proving a level of stress comparable to the healthy model for both types of load.

\section{ACKNOWLEDGEMENTS}

The authors thank the Integrated Research Laboratory (CPBio-FOUFU) and Nucleus of Extension, Research and Teaching of NCCL and Dentin Hypersensitivity.

RESUMO: O objetivo desse estudo foi analisar o comportamento biomecânico de pré-molares inferiores em relação a profundidade da lesão cervical não cariosa (LCNC), tipo de carregamento e condição da restauração, utilizando a análise por elementos finitos. Modelo virtual bidimensional simulando um pré molar inferior hígido foi criado utizando o software de CAD.A partir dessa imagem, cinco modelos foram gerados: hígido (H), três tipos de LCNCs-lesão rasa (SL$0.5 \mathrm{~mm}$ de profundidade), lesão média (ML-1.0mm), lesão profunda (DL-1.5mm), e lesão restaurada (RL). Os modelos foram exportados para o software de CAE (ANSYS Software de Análise por Elementos Finitos), as áreas de todas as 
estruturas foram plotadas e cada modelo foi malhado utilizando um dispositivo controle de malha.Todos os modelos virtuais foram submetidos a dois tipos de carregamento oclusal (100N cada): carregamento oclusal (OL) e carregamento externo (BL) na cúspide vestibular. A intensidade e a distribuição das tensões foram obtidas utilizando os critérios de von Mises e tensão máxima principal $(\sigma 1)$,em Mpa. A análise quantitativa das tensões (MPa) foi identificada em três pontos das LCNCs: parede superior em esmalte, parede de fundo em dentina e parede inferior em dentina. Os resultados apresentaram uma relação direta entre a remoção sequencial de estrutura na região cervical e os maiores valores de concentração de tensões para todos os grupos e para os dois tipos de carga. Para OL, o maior valor de tensão foi $8.8 \mathrm{MPa}$ para DL na parede superior da LCNCs. O BL exibiu maiores valores de tensão em comparação ao OL para todos os modelos. Além disso, BL foi responsável por promover o maior acúmulo de tensão na parede de fundo, $38.2 \mathrm{MPa}$ para DL. A restauração com resina composta foi capaz de restaurar uma distribuição de tensões similar a do modelo hígido, para ambos os tipos de carga. Em conclusão, a extensão da lesão e o tipo de carregamento influenciaram no padrão de distribuição de tensões de pré-molares inferiores. A carga externa parece ser mais crítica para afetar o comportamento biomecânico de pré-molares inferiores, independente do tamanho da lesão. A restauração das LCNCs com resina composta, parece recuperar o comportamento biomecânico similar ao do modelo hígido.

PALAVRAS-CHAVES: Análise por elementos finitos. Lesão Cervical Não Cariosa. Pré-molar.

\section{REFERENCES}

BENAZZI, S.; GROSSE, I. R.; GRUPPIONI, G.; WEBER, G. W.; KULLMER, O. Comparison of occlusal loading conditions in a lower second premolar using three-dimensional finite element analysis. Clin Oral Investig, Berlin, v. 18, n. 2, p. 369-75, 2014. http://dx.doi.org/10.1007/s00784-013-0973-8

BERNHARDT, O.; GESCH, D.; SCHWAHN, C.; MACK, F.; MEYER, G.; JOHN. U.; KOCHER, T.Epidemiological evaluation of the multifactorial aetiology of abfractions. J Oral Rehabil, Oxford, v. 33, n. 1, p. 17-25, 2006. http://dx.doi.org/10.1111/j.1365-2842.2006.01532.x

BORCIC, J.; ANIC, I.; UREK, M.M.; FERRERI S. The prevalence of non-carious cervical lesions in permanent dentition. J Oral Rehabil,Oxford, v. 31,n. 2, p. 117-23, 2004. http://dx.doi.org/10.1046/j.0305182X.2003.01223.X

BORCIC, J.; ANIC, I.; SMOJVER, I.; CATIC, A.; MILETIC, I.; RIBARIC, S.P. 3D finite element model and cervical lesion formation in normal occlusion and in malocclusion. J Oral Rehabil, Oxford, v. 32, n. 7, p. 50410, 2005. http://dx.doi.org/10.1111/j.1365-2842.2005.01455.x

BRANDINI, D. A.; TREVISAN, C. L.; PANZARINI, S. R.; PEDRINI, D. Clinical evaluation of the association between noncarious cervical lesions and occlusal forces. J Prosthet Dent, St. Louis, v. 108, n. 5,p. 298-303,2012.

BRANDINI, D. A.; PEDRINI, D.; PANZARINI, S. R.; BENETE, I. M.; TREVISAN, C. L. Clinical evaluation of the association of noncarious cervical lesions, parafunctional habits, and TMD diagnosis. Quintessence Int, Berlin, v. 43, n. 3, p. 255-62, 2012.

BURROW, M. F.; TYAS, M. J. A clinical trial comparing two all-in-one adhesive systems used to restore noncarious cervical lesions: results at one year. Aust Dent J, Sidney, v. 53, n. 3,p. 235-8, 2008.

CHEE, B., RICKMAN, L. J.; SATTERTHWAITE, J. D. Adhesives for the restoration of non-carious cervical lesions: a systematic review. J Dent,Bristol, v. 40, n. 6,p. 443-52, 2012.

http://dx.doi.org/10.1016/j.jdent.2012.02.007

DEJAK, B.; MLOTKOWSKI, A. Finite element analysis of strength and adhesion of cast posts compared to glass fiber-reinforced composite resin posts in anterior teeth. J Prosthet Dent, St. Louis, v. 105, n. 2, p. 11526, 2011. 
GRIPPO, J. O.; SIMRING, M.; COLEMAN, T. A. Abfraction, abrasion, biocorrosion, and the enigma of noncarious cervical lesions: a 20-year perspective. J Esthet Restor Dent,London, v. 24, n. 1, p. 10-23, 2012. http://dx.doi.org/10.1111/j.1708-8240.2011.00487.x

GRIPPO, J. O.; CHAIYABUTR, Y.; KOIS, J. C. Effects of cyclic fatigue stress-biocorrosion on noncarious cervical lesions. J Esthet Restor Dent, London, v. 25, n. 4, p. 265-72, 2013.

http://dx.doi.org/10.1111/jerd.12024

ICHIM, I. P.; SCHMIDLIN,P. R.; LI, Q.; KIESER, J. A.; SWAIN, M. V. Restoration of non-carious cervical lesions Part II. Restorative material selection to minimise fracture. Dent Mater,Kidlington, v. 23, n. 12,p. 1562-9, 2007.

JOSHI, S.; MUKHERJEE, A.; KHEUR,M.; MEHTA, A. Mechanical performance of endodontically treated teeth.Finite Elem Anal Des, Amsterdam, v. 37, p. 587-601, 2001. http://dx.doi.org/10.1016/S0168874X(00)00059-7

LEE, H. E.; LIN, C. L.; WANG, C. H.; CHENG, C. H.; CHANG, C. H. Stresses at the cervical lesion of maxillary premolar--a finite element investigation. J Dent, Bristol, v. 30, n. 7-8, p. 283-90, 2002. http://dx.doi.org/10.1016/S0300-5712(02)00020-9

LEE, W. C.; EAKLE, W. S. Possible role of tensile stress in the etiology of cervical erosive lesions of teeth. J Prosthet Dent, St. Louis, v. 52, n. 3, p. 374-80,1984.

MICHAEL, J. A.; TOWNSEND, G. C.; GREENWOOD, L. F.; KAIDONIS, J. A. Abfraction: separating fact from fiction. Aust Dent J,Sidney, v. 54, n. 1,p. 2-8, 2009.

MIURA, J.; MAEDA, Y.; NAKAI, H.; ZAKO, M. Multiscale analysis of stress distribution in teeth under applied forces. Dent Mater, Kidlington, v. 25, n. 1, p. 67-73, 2009.

OMMERBORN, M. A.; SCHNEIDER, C.; GIRAKI, M.; SCHAFER, R.; SINGH, P.; FRANZ, M.; RAAB, W.H. In vivo evaluation of noncarious cervical lesions in sleep bruxism subjects. J Prosthet Dent, St. Louis, v. 98, n. 2, p. 150-8, 2007.

ONAL, B.; PAMIR, T. The two-year clinical performance of esthetic restorative materials in noncarious cervical lesions. J Am Dent Assoc,Chicago, v. 136, n. 11,p. 1547-55, 2005.

http://dx.doi.org/10.14219/jada.archive.2005.0085

POIATE, I. A.; VASCONCELLOS, A. B.; POIATE JUNIOR, E.; DIAS, K. R. Stress distribution in the cervical region of an upper central incisor in a 3D finite element model. Braz Oral Res, São Paulo, v. 23, n. 2, p. 161-8, 2009.

REES, J. S. The effect of variation in occlusal loading on the development of abfraction lesions: a finite element study. J Oral Rehabil,Oxford , v. 29, n. 2, p. 188-93, 2002. http://dx.doi.org/10.1046/j.13652842.2002.00836.x

REES, J. S.; HAMMADEH, M.; JAGGER, D. C. Abfraction lesion formation in maxillary incisors, canines and premolars: a finite element study. Eur J Oral Sci, Chichester, v. 111,n. 2, p. 149-54, 2003.

http://dx.doi.org/10.1034/j.1600-0722.2003.00018.x

REYES, E.; HILDEBOLT, C.; LANGENWALTER, E.; MILEY, D. Abfractions and attachment loss in teeth with premature contacts in centric relation: clinical observations. J Periodontol, Chicago, v. 80, n. 12, p. 195562, 2009. http://dx.doi.org/10.1902/jop.2009.090149 
SENAWONGSE, P.; PONGPRUEKSA, P.; TAGAMI, J. The effect of the elastic modulus of low-viscosity resins on the microleakage of Class $\mathrm{V}$ resin composite restorations under occlusal loading. Dent Mater $\mathbf{J}$, Tokyo, v. 29,n. 3,p. 324-9, 2010.

SILVA, N. R.; CASTRO, C. G.; SANTOS-FILHO, P. C.; SILVA, G. R.; CAMPOS, R. E.; SOARES, P. V.; SOARES, C. J. Influence of different post design and composition on stress distribution in maxillary central incisor: Finite element analysis. Indian J Dent Res, Ahmedabad,v. 20, n. 2,p. 153-8, 2009.

http://dx.doi.org/10.4103/0970-9290.52888

SMITH, W. A.; MARCHAN, S.; RAFEEK, R. N. The prevalence and severity of non-carious cervical lesions in a group of patients attending a university hospital in Trinidad. J Oral Rehabil,Oxford, v. 35, n. 2,p. 128-34, 2008.

SOARES, P. V.; SANTOS-FILHO, P. C.; GOMIDE, H. A.; ARAUJO, C. A.; MARTINS, L. R.; SOARES, C. J. Influence of restorative technique on the biomechanical behavior of endodontically treated maxillary premolars. Part II: strain measurement and stress distribution. J Prosthet Dent, St. Louis, v. 99, n. 2, p. 114-22, 2008. http://dx.doi.org/10.1111/joor.12113

SOARES, P. V.; SOUZA, L. V.; VERISSIMO, C.; ZEOLA, L. F.; PEREIRA, A. G.; SANTOS-FILHO, P. C.; FERNANDES-NETO, A. J.Effect of root morphology on biomechanical behaviour of premolars associated with abfraction lesions and different loading types. J Oral Rehabil, Oxford, v. 41, n. 2, p. 108-14, 2014.

SOARES, P. V.; SANTOS-FILHO, P. C.; SOARES, C. J.; FARIA, V. L,; NAVES, M. F.; MICHAEL, J. A.; KAIDONIS, J. A.; RANJITKAR, S.; TOWNSEND, G. C. Non-carious cervical lesions: influence of morphology and load type on biomechanical behaviour of maxillary incisors. Aust Dent J, Sydney, v. 58, n. 3, p. 306-14, 2013.

SOARES, P. V., MILITO, G. A.; PEREIRA,F. A.; ZEOLA, L. F.; NAVES, M. F. L.; FARIA, V. L. G.; MACHADO, A. C.; SOUZA, P. G.; REIS, B. R. The effects of non carious cervical lesions - morphology,load type and restoration - on the biomechanical behavior of maxillary premolars: a finite element analysis. Biosci J., Uberlândia, v. 29, n. 2, p. 526-535, 2013.

STEWARDSON, D.; CREANOR, S.; THORNLEY, P.; BIGG, T.; BROMAGE, C.; BROWNE, A.; COTTAM, D.; DALBY, D.; GILMOUR, J.; HORTON, J.; ROBERTS, E,; WESTOBY, L.; BURKE, T. The survival of Class V restorations in general dental practice: part 3, five-year survival. Braz Dent J., Ribeirão Preto, v. 212, n. 9 ,p. E14, 2012.

TOPARLI, M. Stress analysis in a post-restored tooth utilizing the finite element method. J Oral Rehabil, Oxford, v. 30, n. 5, p. 470-6, May 2003. http://dx.doi.org/10.1046/j.1365-2842.2003.01090.x

VASUDEVA, G.; BOGRA, P. The effect of occlusal restoration and loading on the development of abfraction lesions: A finite element study. J Conserv Dent, Mumbai, v. 11, n. 3,p. 117-20, Jul 2008.

http://dx.doi.org/10.4103/0972-0707.45250

ZUCCHELLI, G.; GORI, G.; MELE, M.; STEFANINI, M.; MAZZOTTI, C.; MARZADORI, M.; MONTEBUGNOLI, L.; DE SANCTIS, M. Non-carious cervical lesions associated with gingival recessions: a decision-making process. J Periodontol, Chicago, v. 82, n. 12, p. 1713-24.

WOOD, I. D.; KASSIR, A. S.; BRUNTON, P. A. Effect of lateral excursive movements on the progression of abfraction lesions. Oper Dent, Seattle, v. 34, n. 3,p. 273-9, 2009. http://dx.doi.org/10.2341/08-100 